\title{
Geç Modern Çağda Eve Dönüş
}

\author{
DOI: 10.26466/opus.634744
}

*

\author{
Figen Kanbir * \\ * Dr. Ör. Üyesi. Siirt Üniversitesi Fen Edebiyat Fakültesi Sosyoloji Bölümü, Siirt/Türkiye \\ E-Posta: f.kanbir@siirt.edu.tr \\ ORCID: 0000-0003-2094-399X

\section{Öz}

Kültürel bir aidiyet bağı yaratması anlamında mekânın insanların ve toplumların yaşamları üzerinde büyük bir önemi vardır. Geleneksel toplumsal tiplerinden bugüne uyum, düzen, güvenlik gibi birçok faktör mekânla ilişkili kullanılmaktadır. Ancak göç ile birlikte mekânsal aidiyetler çözülüşe geçmektedir. Göç, bir mekândan diğerine hareketlilik ve hareket edilen yerde uzun süreli kalma durumunu ifade etmektedir. Dolayısıyla köken bă̆ları olarak ele alacă̆ımız mekânsal birlikteliğin maddi ve manevi boyutlar ortadan kalkmaktadır. Göç geçmişte sadece göç alan ve göç veren ülkeleri etkilemekteydi. Küresel çă̆, diğerlerinden haberdar olmayı ve göç etmeyi kolaylaştırıcı etkenleri sunarken, göçün söz konusu etkileri artık yalnızca muhatap ülkeleri değil tüm dünyayı etkisi altına alan bir sorun haline gelmiştir. Bu bağlamda tartışılması gereken konulardan biri, göç sorununu ortadan kaldırmanın göç edenlerin geriye dönüşü ile mümkün olabileceği konusundaki savunudur. Çalışma dış gö̧̈ün mekânsal dengeyi parçalayıcı etkilerine dikkat çekerken, küreselleşmenin etkileriyle aynı başlangıç noktasından hareket etmektedir. Buna göre hareketlilik bugünün olmazsa olmazıdır. Göç, küresel hareketlilik halinden farklı olarak uzun süreli yerleşiklik kazanma ile bilindik olanı parçalamaktadır. Burada başka bir alternatif çözüm gündeme gelmektedir. Göçün çok boyutlu etkileri karşısında ve yanında geriye dönüş göçü köken ülkeye dönüşün imkânı ile ilişkilidir. Çalışma bu bağlamda, eve dönüşün olasıllğıı kuramsal bir perspektifte ele almaktadır.

Anahtar Kelimeler: Göç, mekân, aidiyet, geri dönüş göçü. 


\title{
Homecoming In The Late Modern Age
}

\begin{abstract}
Space has great importance in the lives of people and societies as it creates the bonds of cultural belonging. In traditional social types as well as contemporary ones, many factors such as harmony, order and security are used in relation to space. However, spatial belonging disintegrates because of migration. Migration refers to movement from one place to another and long-term stay at the destination. The material and immaterial dimensions of spatial unity, which we will treat as bonds of origin, disappear as a result of migration. Migration used to affect only those countries that would send or receive migrants. However, the age of globalisation makes it easier to communicate with others and migrate. Thus, migration is now a problem that not only affects the sending or receiving countries but also the entire world in general. One of the issues that need to be discussed in this context is the idea that the issue of migration can be solved by ensuring the return of migrants back to their countries of origin. While drawing attention to the disruptive effects of external migration, the study begins from the same starting point as the effects of globalisation. Accordingly, mobility is a must today. Unlike global mobility, migration disturbs the familiar patterns because it implies long-term residency. Thus, another alternative solution appears here. Return migration is related to the possibility of returning to the country of origin in addition to, or against, the multidimensional effects of migration. In this context, this study approaches the possibility of homecoming from a theoretical perspective.
\end{abstract}

Keywords: Migration, space, belonging, return migration 


\section{Giriş}

Tarihsel devirlerin neredeyse tümünde evin koruyucu ve kapsayıcı iç dokusu, yaşamı tüm yönleriyle belirlemektedir. Buna rağmen geç modern çağın koşulları, kendi iç dengeleri içinde, evde kalmak, evde olduğunu hissetmek bahsini tartışmalı hale getirmektedir. Bu sadece aile yapısının içinde yer aldığı mikro ilişkileri ve gündelik hayatı değil kentleri, ülkeleri, dünya düzenini de etkilemektedir. Bunlardan biri olan göç, uzun süreli yer değiştirme hareketi olmakla birlikte kişinin hayatın belirlemektedir. Göç, yer değiştirenlerin temel(ler)ini ya da köken bağlarını alt üst ederek yaşamları için zorunlu göçü dışarıda tutarsak, daha iyi ve yeni bir düzen aramaları umudunu içerir.

İnsan, ontolojik bağlllıklar içerisinde, kendisine güvenli ve bilindik bir yaşamı olası kılmaktadır. Bununla birlikte yer değiştirmekle sarsılan bu ideal, göç edilen yerdeki kültürün, dilin, dinin yaşatılmasıyla bir ölçüde varlığını sürdürür. Sürdürmenin olasılığı, ev sahiplerinin misafirperverliğiyle de alakalıdır. Entegrasyon ve asimilasyon ${ }^{1}$ bu stratejinin iki uç kutbu olarak alınabilir. Söz konusu durum, gidilen bölgenin, ülkenin değerlerinin göçmenlere olumlu veya olumsuz yansımasıdır. Başka bir alternatif var mıdır ya da bulunabilir mi sorusu için çokkültürcü politikalar önemli bir yere sahiptir. Ancak geriye dönmek, bu iki farklı stratejinin dışında bir yaşama olasılığını barındırır. Bu eskiye dayalı düzene dönüştür; bu süreç her zaman (beklenildiği gibi) olumlu bir sonuç doğurmamaktadır.

Eve dönüş kapsamlı ve problematik bir sorunu içine almaktadır. Sosyal bilimlerde geri dönüş göçü olarak adlandırılan eve/kökene dönüş miti, fiziksel bir geriye dönüş miti olmaktan farklı olarak, çok boyutlu bir sorun olarak karşımıza çıkmaktadır. Söz konusu sorunların birer getirisi/sonucu olarak gördügüumüz eve dönüş göçü toplum, kültür ve kimlik bahsi üzerinden arada kalmışlığı içermektedir. Öyle ki göçmenler ne bulundukları ne de geçmişte ait oldukları yerde evlerinde hissetmektedirler.

\footnotetext{
${ }^{1}$ Ayşe Akalın'a göre bir göç dalgasının döngüsel mi kalıcı olarak mı devam edeceğini belirleyen önemli bir unsur, göçü alan ülkenin gösterdiği siyasal tavırdır (2018, s.94). Iklime bağlı, yaşam biçimi veya emekli göçünün ağırlığını Muğla ilinde yaptıkları alan çalışmasında inceleyen Tuna ve Özbek, göç ile ilgili yapılmış pek çok çalışmada (Castles ve Miller, 2018) olduğu gibi, entegrasyon ve asimilasyonu, ulusdevlet kimliğini oluştururken iki temel strateji olarak açıklamaktadır (2018, s.145).
} 
Küresel hareketlilik hali, uluslararası göç bağlamında uzun süredir mevcuttur. Ancak göç, her zaman göçmenlerin istekleri dahilinde gerçekleşmediği gibi çoğu kez var olan sorunlar karşısında bir çözüm veya kurtuluş yolu gibi görülebilmektedir. Bu durum bizi, Hayriye Erbaş'ın deyimiyle "göçmenlerin krizi yaratmadığı, tam tersine krizlerin göçmenleri yarattı̆̆ı" sayıtlısına götürür (2019, s.263). Bu çalışma bu bakımdan göç edenlerin kendi geçmiş bağlarıyla yakından ilgilidir. Bu durumu ortak mekân ile bir arada düşünmeliyiz. Göçmenlerin iş ve yaşam konusunda sahip oldukları bilgi düzeyi, içine girdikleri kültürün avantaj ya da dezavantajlarını sorgulamak adına önemli bir seçenek sunmaktadır. Diğer taraftan içinde yer aldıkları yeni topluluğa bağlılık derecelerinin ölçülüğü, kültürel geçmişlerinin izini taşımaktadır. Burada dâhil olunan kültüre yakınlık ve uzaklık, temel belirleyicidir.

Philippe Robert'a göre insan toplumları tarihinin büyük bölümünde sosyal ilişkiler kesinlikle yöresel düzlemde sınırlıydı. Bundan dolayı o, söz konusu dönemlerde insanların tanışıklığına dayalı bir toplumdan söz edilebileceğini öne sürüyordu (2002, Bauman 2017, s.28). Bugün ise maddi ve manevi göstergeleri geleneksel sınır aralıklarıyla çizilmiş toplumdan yeni bağlayıcılara geçiş söz konusudur. Burada kontrol ağlarının, yapay kontrolsüzlüklerle yer değiştirmesi söz konusudur; herkes için kutsallaştırılmış bariyer noktalarının var olmasından güçlü olana hizmet eden, bunun görünürlülüğünün giderek arttığı akışlar uzamına doğru mesafe alınmıştır. Sözgelimi 2015 Dünya Göç Raporu'na göre, doğdukları ülkenin sınırları dışında yaşayan insan sayısı 244 milyonu bulmaktadır. Geçmiş verilerle kıyasland1ğında, (1990'da 153 milyon, 1970'de ise 84 milyon) hızlı bir atışın olduğu söylenebilir (IOM 2018). Bu veri, geleneksel aidiyet değerlerinin kısmen çöktüğü bir dünyada, yeni aidiyetler yaratma olasılıklarını dikkate almak zorunluluğunu ifade etmektedir. Dolayısıyla söz konusu insanların nereye ait hissettikleri veya olacakları konusu artan bir karmaşa içermektedir.

Tarihsel devirlerin tümünde, paydaş kültürün tarifi farklı yönlerden ele alınabilir. Burada göçle ve göçmenlerle beraber yeniden ele alınan bu ideal, ortak mekânda bulunmakla alakalı düşünülmelidir. Zira fark edilebilirliğin derecesi yerleşme prensibinin uzunluğuyla değerlendirme bulmaktadır. Dolayısıyla sıla özlemi olarak ortaya çıkan da, göç edenin uzun süreli “yabancı"lığının getirisidir. 
Göç çalışmalarına yöntemsel açıdan bakıldığında temelde iki farklı yönelim mevcuttur: Göç olgusunun sonuçlarını ve etkilerini araştırarak, göçün makro düzeyde dinamiklerini ortaya koymaya çalışan makro çalışmalar ve göçü yaşayanların göç deneyimlerine odaklanarak göçün ayrıntılarını daha çok mikro düzeyde ele alan çalışmalar (Kümbetoğlu, 2018, s.50). Çalışma, fenomenolojik bakış açısından faydalanarak, makro ve mikro düzeyde göçü anlamaya çalışmaktadır. "Tersine göç mümkün olabilir mi?" çalışmanın temel sorusu olmakla birlikte, bunun olasılıkları ülkeler ve bireyler ölçeğinde mekanâ varlık kazandıran düzen, kontrol, uyum gibi pek çok değişkenin yer değiştirmesi anlamında dikkate değer bir sorundur. Bu sorun, günümüz koşullarında, küreselleşmenin yarattığı etkiler dışında dikkate alınamayacak denli büyüktür. Çalışma kapsamında ise konu, yalnızca kuramsal ${ }^{2}$ bir değerlendirme ışığında dikkate alınacaktır.

Bu bakımdan çalışmamız, göç çalışmalarının çoğunda olduğu gibi göçün nedenlerine ve hedef ülkenin sorunlarına değil, kaynak ülkenin tekrar cazibe merkezi olmasını tartısmaya açıyor. Göç edenlerin ülkelerine dönmeleri ülkelerinden gitmeleri kadar ağır bir sorundur. Bu yalnızca göçmenlerin kendi kişisel deneyimleri ile değil, fakat göç alan ve veren ülkelerin de bir sorunudur. Bu bakımdan, kısmi de olsa, çözüm içermektedir. Bu bakımdan eve dönüş, göçmenlerce göçmenlerin ağır bir yük oluşturduklarını düşünenlerce arzu edilmektedir. Ancak çözüm, her zaman iyi hal demek değildir. Nasıl ki göç deneyimi literatürde, gönüllü ve zorunlu olarak geniş bir şekilde tartşılıyorsa, tıpkı bunun gibi, geri dönüş göçü de böyle bir sınıflandırmaya tabidir.

\section{Mekânın Oluşturucuları ve Yerliliğin Kültürel Dayanakları}

İnsanın varlık göstermesinin en önemli koşulunu kültür oluşturmaktır. Ünlü Amerikalı antropolog Clifford Geertz'in eşsiz tarifiyle bizler kendimizi kültür yoluyla tamamlayan eksik, tamamlanmamış hayvanlarız. İnsan kültürü yaratarak, kültürü dilde anlamlı kılarak kendi kendisini yaratmıştır. İnsan olmadan kültür olmaz, kültür olmadan insan olmaz (2010, s.67-8).

\footnotetext{
${ }^{2}$ Çalışmaya uygulama (nitel görüşme) maksatı başlamış olmamıza rağmen evrenin büyük olması ve burada gereken sınııın koyulamaması anlamlı bir örneklem bahsi konusunda sıkıntı yaratmıştır. Başka bir açıdan ise, belli bir bağlamda veriyi içine alacak şekilde örnekleme erişilememiştir. Bundan dolayı çalışma kuramsal boyutta ilerlemiştir.
} 
Genel bir tanımlamayla kültür, insana varlık sahası açarak, ona yaşam alanı sunan soyut bir belirleyicidir. Ancak bu soyut belirleyici, (karşılıklı etkilenmeyi de içine alarak) somut olanı bütün yönleriyle içine almaktadır ve yönlendirmektedir.

Gündelik yaşam dünyası, bizim dünyaya gelişimizden önce var olan ve bizden önce de başkalarınca düzenlenmiş ve yorumlanmış bir dünyadır. $\mathrm{Bu}$ dünya, bize geçmiş insanların deneyiminden miras kalmış olmakla birlikte, hayattaki deneyimlerimizden oluşan bir bilgi stokuna dayanır (Schütz, 2018, s.85). Bu tanımlamada dikkat çeken diğerleriyle birlikteliğin varlı̆̆ıdır. Geçmiş olduğu kadar bugün ve gelecekte de birlikteliğin sağlamış olduğu avantajla kendimize ait bir saha oluştururuz. Öyle ki, insan olarak bizler, verili bir dünyanın ekseninden kendine ait bir dünya yaratma peşine düşeriz. Burada esas olan ontolojik bir güvenlik sahası yaratmaktır.

Yargılarımız içinde yaşadığımız dünyaya ilişkindir. Bilgi bir doğa olgusu olarak, bilen organik varlıkların yaşantısıdır (Husserl, 2017, s.13,15). Gündelik yaşam dünyamız, başından itibaren hemcinslerimizle paylaştı̆̆ımız, özneler arası bir dünya, hepimizin ortak dünyasıdır. Bu dünya, ortak iletişimle oluşturulmuş anlama üzerinde kurulmuş bir dünya olarak başkalarına yöneldiğimiz, karşılıklı tinsel deneyimlerimizle motive edilmiş gerçekliğe dayanmaktadır (Schütz, 2018, s.186-7). Bu gerçekliğin önemli bir kısmını Geertz'in "ilksel bağlılıklar" adını verdiği akrabalık ve kan bağları, dinsel, dil ve âdetler oluşturur. Bu yalnızca kişisel bağlllık, gereksinim ve ortak çıkar ya da zorunlu yükümlülükten ibaret olmayıp mutlak bir anlamdan ötürü vardır. Bu tür ilksel bağların gücü ve önemi kişiden kişiye, toplumdan topluma ve zamandan zamana değişiklik gösterir (2010, s.289). Değişmeyen, bunların bir topluluğa özgü belirleyenler olarak, diğer toplumların kültürel özelliklerinden ayrılmasıdır.

Yalnızca ortak anılar ya da değerlerle değil, aynı zamanda ortak kurumlar ve pratiklerle de ilgili olan toplumsal kültür, hem kamusal hem de özel alanları kucaklayarak üyelerine sosyal, ekonomik, eğitsel, eğlenceye ilişkin tüm insan etkinliklerine özgü anlamlı hayat tarzları sağlayan bir kültürdür. Bu kültürler zaman içerisinde oluşur, belli bir toprak parçasında yaşar ve bir dile dayanırlar (Kymlicka, 1998, s.130). Bu çalışmanın ana savı ise, ortak mekânın bağlayıcılığının kişileri birleștirdiği yönündedir. Bu minvalde, en mahrem ilişki ağlarının şekillendiriciliğinin üstlenildiği evden (oikos) kamusal alana, toplanma ve aitlik kazanmaya insanları birleştiren, mekândır. 
İnsanla mekân arasındaki ilişki bir karşılıklılık esasına dayanır. Mekâna anlam veren insan iken, insanı da mekândan bağımsız değerlendirmeyiz. Bu ilişki, mekânları toplumsallaştırırken; insanları da mekânsallaştırmıştır. Buradan üç etkileşim boyutu çıkarılabilir: İnsanın mekân üzerinde belirleyici etkisi, mekânın insan yaşamı üzerindeki şekillendirici etkisi ve mekânın bu ilişkilerin gerçekleşmesinde fiziksel olduğu kadar toplumsal bir sahne olması (Karakaş, 2019, s.19). Dolayısıyla yerlilik ${ }^{3}$ söz konusu edildiğinde, mekânın toplum ve toplumun üyelerine aidiyet bağları yarattığından bahsedilebilir.

İnsan için mekânlar, kimlik edinme ve onu sahiplenmede, önemli bağlayıcılardır. Mekânın ne olduğu, kimliğin oluşturulmasında ve toplumların gelişmişlik seviyesi hakkında bilgi sahibi olmamıza olanak tanır. Bunlardan biri ve belki en önemlisi olan ev, kimliğin kurucu inşasının ilk yeri olarak geleneksel kültürel özelliklerin kuşaktan kuşağa aktarılmasını sağlar. Burada bireyler geleneksel toplumları ayakta tutan samimi ilişkileri merkeze alarak yakın akrabalık ilişkilerini sağlamlaştırır.

Türk Dil Kurumu Sözlüğü'ne göre ev, bir kimsenin veya ailenin içinde yaşadığı yer, konut, hane ${ }^{4}$ olarak tarif edilmiştir. Diğer taraftan yine aynı sözlüğe göre mekân, ev ve yurt anlamına gelmektedir. ${ }^{5}$ Bu bakımdan ev, içinde yer alanlar için müşterek değerler silsilesiyle örülmüş, toparlayıc bir şemsiye özelliği sergilemektedir. Bu toparlayıcılık dışarıyı içeriden, içeriyi dışarıdan ayırarak hane halkını bir araya getirir. Ev mahrem olanın tarif edilmesi anlamında ailenin birleşme noktasını sembolize eder. Böylelikle içeride olanın tarif edildiği sahanın gösterenidir. Bir şeye ya da bir yere ait olmak için başlangıç buradan yakalanabilir.

Burada Hannah Arendt'i anımsayacak olursak, kamusallıktan kaçmanın ve karanlıkta kalmamanın en emin yolunun özel mülkiyet olduğu söylenebilir. Bu, özgürlük ve zorunluluk arasındaki bir çelişkinin ürünüdür. Erken modern çağda bireyin geçimine ve türün bekasına yönelik etkinliklerin tümü olarak anlaşılan yaşam sürecinin zorunluluğuyla ilgili her şeyin, insani var oluşun özel alanında gizli/saklı tutulması gereken bedensel parçaların oluşturduğu kesindir. Ancak kamusal alandaki görünüm arttıkça mülk

\footnotetext{
${ }^{3}$ Çalışmada yerlilik kavramı, aidiyet geliştirilen mekânla ilişkilendirilerek kullanılmıştır.

${ }^{4}$ http://www.tdk.gov.tr/index.php?option=com gts\&arama=gts\&guid=TDK.GTS.5ca32a0a1cfbc3.62497 $\underline{161}$

${ }^{5}$ http://sozluk.gov.tr/
} 
sahiplerinin devlet korumasına daha fazla ihtiyaç duyduğu söylenebilir (2013, s.120-2). Bu bağlamda özgürlüğün özel alana temel oluşturulduğu söylenebilirse de, özel alanlar arasındaki uyumu ve birlikteliği devletin sağlayabileceği söylenmelidir. Bu bakımdan ulus devletin varlık kazanmasının en önemli noktalarından birisini zorunluluk oluşturmaktadır. Zorunluluk yerel kültürel değerlerin oluşturucusu olduğu kadar diğer devletlerden farkı ile de adından söz ettirir.

Özgürlük seçimlerin çok sayıda tercih arasından yapılmasını gerektirir ve toplumsallık kültürü bu seçenekleri bizler için anlamlı kılar (Kymlicka, 1998, s.139). Modood'a göre siyasi açıdan en dikkate değer kültürler, uluslardır (2014, s.55). Modern toplumlarda geleneğin ve geleneksel kurucu aidiyet değerlerinden biri olan evin baskın etkisi yerini ulus devlete bırakmıştır. Burada evin güven sağlayıcı donanımı, mekânın evden bağımsız artan önemiyle başka bir alan ve başka bir kimlik tasarımı ile yer değiştirmiştir. Vatandaşlık modern dönemde, ulus devletin nüfusunun yoğunluğunun, mekânsal genişlemesinin ve iletişimde kalma zorunluluğunun getirdiği bir yeniden inşa sürecidir. Ulusal kimlik, biz ve onlar arasında sinır çekmek için devlet ve onun temsilcileri tarafindan oluşturulmuştur; katılımcllarından kesin ittifak ve özel sadakat talep etmektedir (Bauman, 2017, s.32). Ulus, bir kimliğin içinde olmak bakımından dâhil olmayı ve diğer kültüre içinde olduğu kültürün gözüyle bakabilmeyi gerektirir. Oradaki belirleyici birtakım özellikler, farklı kültürlerin tanımlanmasına ve ayırt edilmesini olası kılar.

Modern millet fikrinin ve onunla bağlantılı her şeyin temel karakteristik özelliği modernliğidir (Hobsbawn, 2017, s.30). Millet fikrinin ortaya çıkabilmesi için milliyetçilik fikrinin gelişmesi gereklidir. Belli bir mekânda, ortak dil, din, ekonomi gibi bağlayıcılar milliyet fikrinin gelişmesinde belirleyici özelliğe sahiptir. Gerçek bir milliyet fikrinin ortaya konulması için, farklı küçük olasılıkların (dil, din, etnik köken ve benzeri) göz ardı edilmesi gerekmektedir (Hobsbawn, 2017). ${ }^{6}$ 18. yüzyılın sonuna doğru milliyetçiliği üreten şey, dinsel kesinliklerin aşınmasıdır. Ulus-devletlerin yeni ve tarihsel oldukları kabul edilmekle birlikte, ulusun ezeli bir geçmişten kaynakland1-

\footnotetext{
${ }^{6}$ Hobsbawn milliyetçiliğin günümüzde giderek etkisini yitirdiğini/yitireceğini öne sürmektedir. Bu noktadan yola çıkarak milliyetçilik ve millet kavramlarının kökenleri ve tarihsel değişimleri üzerine eğilmektedir.
} 
ğına ve sınırsız bir geleceğe doğru ilerlediği kabul ediliyordu (Anderson, 2017, s.25-6). Yirminci yüzyılın ikinci yarısına kadar ulus devlet, kendi sınırları içinde yaşayan kimselere kan ya da toprak bağı kuralına göre vatandaşlık hükümlerini tanımlıyordu; ekonomik, toplumsal ve siyasal hakların kullanımın bu ölçülere göre belirliyordu (Abadan-Unat, 2017, s.342). Bu bağlamda kapitalizm, teknoloji ve insanın dilsel çeşitliliğe olan mahkûmiyetinin yeni bir cemaat tarzının hayal edilmesini mümkün kıldığı ve bu yeni tarzın modern ulusların morfolojisini hazırladığı söylenebilir (Anderson, 2017, s.62).

Ancak tarihsel devirlerin bütününde etkili olan göç, ulus-devletin temelinde yer alan vatandaşlık ve köken bağlarını sorgulamamızı olası kılmaktadır. Göç günümüz dünyasını şekillendirmektedir. Çalışmanın buraya kadar olan kısmı, mekânsal aidiyet bağlarını genel hatları ile ele almıştır. Sonraki başlıklarda ise, göçün ne olduğu üzerinde durulacaktır.

\section{Göç Deneyimi ve Yerliliğin Mekândan Ayrı Tanımlanması}

İnsanlar "doğal süreçte" toplumun değerlerini ve bireyden beklentilerini öğrenirler. Ancak doğal süreçteki bir aksaklık, uyumsuzluğu ve "yeniden toplumsallaşma"nın gerekirliliğini açığa çıkarır (Adıgüzel, 2019, s.54). İşte bu bölüm, yerlilerin göç sonucunda ortak mekânın dışında kalması ile yeniden bir mekâna ait olma süreçlerinin nasıl gerçekleşeceğini dikkate alıyor. Nurdan Türker'in antropolojik çalışmasında belirttiği gibi, "Göç hem gidenler hem de kalanlar açısından kimliklerini sorunsallaştıran ve mekânsal duyumlarında sarsıntı yaratan bir deneyimdir" (Türker, 2015, s.51). Kimi kez, ortak mekânı oluşturan kimseler içeridekileri tanıdık bir imajla sahiplenirlerken, dişarıda kalanların içeridekilerce tarifi sorunlu bir etiketle örtüştürebilmektedir. Bu durumu, konumuz açısından, göçün sosyal bilimlerde artan önemiyle bir arada düşünmeliyiz. Göçle birlikte varsayımdan nesnel bir gerçekliğe dönüşen farklı gruplar ülke içerisinde önce bir yabancı, daha sonra bir mukim haline gelmişlerdir. Ancak söz konusu mukimliğin sınırları, yerliliğin (mekânsal) sınırlarının dışında kalmaktadır.

Göç bireylerin ya da grupların sembolik ve siyasal sınırların ötesine, yeni yerleşim alanlarına ve toplumlara doğru daimi veya yarı-daimi hareketini 
içerir (Marshall, 1999, s.685; Faist, 2003, s.41). Kisaca hareketlilik ${ }^{7}$ anlamına gelen göç, insanların bir bölgeden bir başka bölgeye gerçekleştirdiği, kayıtlı tarih boyunca insan türünün yayılışıyla alakalı düşünülmesi gereken bir kavramdır. Göç modern bir olgu değildir; fakat modern çağda hız kazanarak küreselleşmenin bütünleşme sürecini hızlandırmıştır (Giddens ve Sutton, 2014, s.109-110). Sözgelimi ilk insanlar, avcı ve toplayıcıdı; bu nedenle göçebeydi. Onların çocukları olan Homo Sapines türü de sonraki tarihlerinin büyük bir kısmında göçebe kaldı. 1.5 ila 2 milyon yıl kadar önce Homo adlı cins iki ayağı üzerinde duran Australopithecus'tan meydana geldi. İki tür de doğuştan ve doğası gereği göçebeydi (Bauman, 2018, s.59-60). Bu bakımdan göç, insan tarihiyle benzer bir başlangıç noktasına sahiptir diyebiliriz.

Tarihin bütün devirlerinde göçlerin değişimi de beraberinde getirdiği söylenebilir. Göçler farklı toplumlar arasındaki karmaşık bağlantılardan ortaya çıkar ve yeni bağlantıların oluşmasına yardımcı olur. İnsanların hareketliliği, dünyanın Kuzey-Güneyinde olduğu kadar, azgelişmiş dünyada kalkınma stratejilerinin temel konusudur (Castles ve Miller, 2008, s.215). Ancak söz konusu göçlerin her zaman ülkeler için olumlu olduğu söylenemez. Sözgelimi göç kontrolü ve güvenilirliği de tehlikeye düşürebilir. Düzensiz göç hareketleri ulus devletlerin temellerini alt üst edebilir. Bunun için düzenli ve kontrol edilebilir göçün ulusal ve uluslararası arenada önemli bir yeri olduğu söylenebilir (Akçapar, 2018, s.111-2). Bu bağlamda göçün özellikle de düzensiz göçün, sığınmacı ve mültecilerin güvenlikleştirilmesi ile bağlantılı olarak siyasallaşması, bölgesel ilişkilere yaptığı etkilerin vurgulanması 1990'lı yıllardan itibaren gözlemlenen gelişmelerdendir (IhlamurÖner, 2018, s.41). Dolayısıyla düzensiz göçün, oldukça yakın dönemli ilişki ağlarının birer getirisi ve sonucu olduğu söylenebilir. Diğer taraftan göç, uluslar ve uluslararası birçok bağlamda olumsuzluk getirebileceği gibi, birey ve aile için de bilinmeyene yolculuk etmek, göç edilen yerin yabancısı olmak bakımından risklerle dolu bir yolculuktur (Adıgüzel, 2019, s.3).

\footnotetext{
${ }^{7}$ Ancak buradaki tanımlamamızın karşısında, Stephen Castles'in ifade ettiği gibi, modern insan hareketliliğini ifade etmede hareketliliğin tek başına yeterli olmadığını öne sürülmelidir. Göç, istenmeyen, sürgün, tehcir, işgal ve savaş gibi nedenlerle yapılan zorunlu göçleri ifade etmekte daha çok kullanılmaktadır. Oysa eğitimli, beyaz yakalı ve kalifiye kişilerin yer değiştirmesi ise hareketlilik kavramı önerilmektedir. çünkü hareketlilik açık toplumu, yaşam tarzı hareketliliğini, göç ise eşitsizliği, istenmeyen kötü durumları çağrıştırmaktadır (Adıgüzel, 2019, s.13-4).
} 
"Göç tarihin her döneminde yaşanuyor olsa da ekonomik, politik ve doğal felaketlerle belli dönemlerde göç dalgaları biçiminde gerçekleşmekte ve bu tür göçler hem göç veren ya da kaynak ülke, hem göç alan ya da hedef ülkeleri etkilediği gibi neredeyse tüm dünyadaki ekonomik, politik uluslararası ilişkileri de etkilemektedir" (Erbaş, 2019, s.265; Castles ve Miller, 2018, s.29). Genel bir değerlendirme ile önceleri ağırlıklı olarak köle emeği, sonrasinda büyük oranda sanayileşmenin etkisiyle sözleşmeli iş̧̧ilik olarak gerçekleşen (emek) göç biçimleri, 1980'li yılların ortalarından itibaren sığınmacı ya da kaçak göçmenlik biçiminde ortaya çıkmıştır (Castles ve Miller, 2018, s.71-91, 144).

Göçün ortaya çıkmasında dünyadaki küresel ölçekli gelişmeler belirleyicidir. Büyük çaptaki göç hareketleri Avrupa devletlerinin emperyalist atılımları ile başlamakta ve köleliğin ortadan kalkmasıyla üçüncü dünya ülkeleri ucuz işgücü görülerek göçe zorlamasıyla gerçekleşmiştir. Birinci Dünya Savaşı'nın sonuçları ile imparatorlukların yıkılması ve yeni devletlerin kurulması, İkinci Dünya Savaşı'ndan sonra sömürgeciliğin tasfiyesi ve bağımsızlık hareketleriyle şekillenmiştir (Abadan-Unat, 2017, s.75-7).

Çağdaş dünyada hâkim örgütlenme biçimi ulus devletlerdir. Ulus devletler meşruiyetlerini kendi vatandaşlarının amaçlarını temsil ettikleri iddiasından alırlar (Castles ve Miller, 2008, s.55). Ulus-devletlerin coğrafyası göç için önemli içeriksel faktördür ve devletlerarası sinırlar göç hareketini tanımlamada yardımcıdır. Kişi belirlenen alanda evdedir; bir üyedir ve vatandaştır. Dâhil olduğu alanın dışında ise yabancıdır (Bartram, Poros, Monforte, 2017, s.47). Bu bağlamda çalışma açısından göçün bireye olduğu kadar hayali cemaat yapıları üzerindeki etkisi de dikkate değer konulardan biridir. "Ulus-devlet merkezli bakış açısı göçü sınır aşan bir "sorun" alanı olarak ele alırken vatandaşlık ve sosyal refah rejimlerine meydan okuyan bir olgu olarak görmektedir" (Ihlamur-Öner, 2018, s.22). Başka bir deyişle DeLaet'e göre ulus devlet merkezli yöntemsel milliyetçilik uluslararası göçü ulus devletin sinırlarına, düzenine, vatandaşlık ve sosyal refah rejimlerine meydan okuyan bir olgu olarak görür. Vatandaşa ya da yerliye karşı göçmeni yabancı olarak tanımlar (2007, Öner 2018, s.14).

"Göçmenler "ulus" değildir ve yurtları yoktur. Onların özgünlüğü asıl olarak aile hayatlarında ve gönüllü kuruluşlarda kendisini gösterir ve kurumsal bütünleşmelerle çelişmez. Onlar egemen kültürlerin kamusal kurumlarında yer alırlar ve egemen dil(ler)i kullanırlar" (Kymlicka, 1998, s.43- 
4). Ancak süregiden uluslararası göç hareketleri gittikçe daha fazla ülkenin etnik farklılığını arttırmaktadır. Bu ulus devlet ve vatandaşlık kavramının sorgulanmasına yol açacaktır (Castles ve Miller, 2008, s.22).

Farklı ülkelerin göç deneyimlerini dikkate alarak yaptıkları çalışmada Castles ve Miller, ülkelerin göç konusuna yaklaşımdaki farklılıkları, tarihsel olarak ulus devlet inşa süreçleri arasındaki farklara dayandığını ileri sürmektedirler (2008, s.324). Bazı göçmen ülkelerinde, göçmenlerin vatandaş olmaları oldukça zordur. Bazılarında ise göçmenler kültürel asimilasyon karşılığında vatandaşlığa kabul edilmektedirler. Üçüncü grup ülkede ise, göçmenler kendi kültürel kimliklerini koruyarak vatandaş olabilirler (Castles ve Miller, 2018, s.353).

Göç sınıfsaldır; göç türü ait olunan sınıfa göre farklılık göstermektedir. Zengin göçmenler için özgürlük anlamın taşırken, yoksullar için zorunlu bir yer değiştirmedir (Erbaş, 2019, s.293). Ekonomik anlam taşıyan hareketlilik iki bağlamda değerlendirebilir: Düşük gelirini yükseltmek ve orta ya da yüksek düzeydeki geliri ile daha yüksek bir yaşam standardı yakalamak (Tuna ve Özbek, 2018, s.25). Aynı zamanda savaşlar, soykırımlar, doğal felaketler gibi zorunluluktan kaynaklanan göç de daha güvenli bir yer değişimi olarak bu iki maddeye eklenebilir.

John Rawls, "gerçekçi bir ütopya" olarak sunduğu insan toplulukların, ulus ya da devlet olarak değil, halklar olarak tarif etmektedir. Göçün, doğal nedenler ve geleneksel çıkar çatışmaları ve savaşlardan kaynaklandığını; göçe yol açan bu nedenlerin sonra ermesiyle, ortadan kalkacağını öne sürmektedir (2006, s.7). Bu nedenler fazla iyimser olmakla birlikte, kuşkusuz modern ulus devletleri ve onların vatandaşlarını ele alırken farklı bir perspektif sunmaktadır. Ancak bu bakış açısı 21. yüzyıl göç dalgasını açıklamaya çalışırken aynı incelikli çözümü sunmamaktadır. Çünkü Rawls kuramını oluştururken düzgün veya adil bir topluluk tasarımından yola çıkar. Oysa bugün bu stabil toplulukların yaşam beklentileri ile bugünün karmaşık toplumlarının beklentileri arasında bir benzerlik görünmemektedir. Topluluklar farklı olduğu gibi göç de yok olmamakla birlikte düzensiz bir atış göstermektedir.

Tarihin başlangıcından sanayi toplumuna kadar göç, kültürel ve ekonomik hareketliliğin gelişmeye yön verdiği avantajlı bir durumken; küresel çağda artan hareketlilikle kolaylaşmış, ülkeler, vatandaşlar ve onların varlık koşulları için avantajdan çok dezavantaj konumuna gelmiştir (Özgöker ve 
Doğan, 2019, s.16). Bu bakımdan, ulus devletler tarafından göçün kontrolü gerekli görülmeye başlanmıştır. Bu bağlam bizi göçün modern gerçekliğinden farklı olarak geç modern çağdaki gerçekliğini okumaya yönlendiriyor. Göç erken modern dönemde ulus devlet kimliği üzerinden şekil bulmaktaydı. Bugün ulus devletin vatandaşlar olarak kucakladığı yapı son bulmamakla birlikte yeni eklentilerle yaşamına devam etmektedir. Çalışmanın bir sonraki başlı̆̆ında bu konuya temas edilecektir.

\section{Geç Modern Çağda Göç ve Göçmenler}

Geç modern dönemde, diğer her şeyde olduğu gibi, göç deneyimi de değişim göstermiştir. Göç sınırlı bir alanda belli kesimden insanların tercih ettikleri bir olgu iken bugün kitlesel bir harekete bürünmüştür. Bu bağlamda sözü edilen dış göçtür. Çünkü dış göç, bilindik olanı parçalaması anlamın$\mathrm{da}$, insan ve toplum üzerinde derin etkiye sahiptir. Uluslararası göç, çok sayıda bağ ile çok sayıda ulus-devlet içinde iki ya da daha çok konumu ve hareket edenlerle kalanlar arasındaki çeşitli bağları özetleyen; çok boyutlu ekonomik, siyasi, kültürel ve demografik bir süreçtir (Faist, 2003, s.30). Uluslararası göç, ne geç 20. yüzyılın ne de modernitenin bir icadıdır. İnsanlık tarihinin birer parçası olmakla beraber göçün, 1945 'ten bu yana ve özellikle 1980'lerin ortalarından beri önemi ve hacmi artmaktadır (Castles ve Miller, 2008, s.7). Bu durumun temel nedeni küresel dünyada mekânın işlenmiş/merkezileşmiş/normalleştirilmiş hale gelmiş; insan bedeninin doğal kısıtlamalarından kurtarılmış olmasıdır (Bauman, 2010, s.25). Küresel yaşam tarzı hem fiziki hem de kültürel ve sosyal hareketliliğe yön vermiştir. Göç, "iletişimsel özgürlüğün" bir getirisi olarak hareket serbestisiyle bir arada anılmaya başlamıştır (Benhabib, 2018).

1945 sonrası dönemde ve özellikle 1980'lerin ortalarından bu yana göçsel hareketlerdeki patlama uluslararası göçün küresel dönüşümlerin önemli bir parçası haline gelmiş̧tir. Bu üretim, dağıtım ve yatırımın uluslararasılaşması ve eşit derecede kültürün küreselleşmesiyle alakalıdır. Soğuk Savaş'ın sona ermesi ve Sovyet Bloğu'nun çöküşü küresel yeniden yapılanmaya yeni boyutlar ekledi. Bunlar arasında gelişmiş kapitalist ülkelerin bazı yatırımlarının Güneyden Doğu Avrupa'ya doğru adres değiştirmesi ve önceden yal1tılmış göç akışlarına girilmesiyle birlikte, Doğu-Batı göçü arttı (Castles ve Miller, 2008, s.126). Bu dönemdeki büyük ölçekli göçlerin temelinde ekonomi yer almakla birlikte ekonomik sebeplerin köklerini sosyal, kültürel ve 
siyasi değişim süreçleri oluşturmaktadır (Castles ve Miller, 2008, s.126-7). Örneğin Abadan-Unat tarafından Almanya'daki yabancı göçmenlerle ilgili yapılan araştırmanın sonuçları göstermektedir ki; gidenlerin beşte dördü gitmeden önce de iş sahibi idi. Onları Almanya'ya gitmeye iten nedenler işsizlik değil, yurtdışında ödenen yüksek ücretler, kısa zamanda önemli tasarruf yapma ümidi, yeni bilgiler edinebilme beklentisi ve dünyayı tanıma arzusu olmuştur (2017, s.134). Söz konusu göçmenler başlangıçta (AbadanUnat, 2017) yerleşmek değil, birikim sağlayarak yurtlarına sermaye biriktirmek ve biriktirdiklerini döndüklerinde değerlendirebilmek arzusundadırlar.

Bu duruma eklenebilecek bir diğer şey, insanların bireysel olarak değil, grup olarak göç etme eğilimindede olduğudur. Göç yalnızca göçmenleri değil, aynı zamanda göç veren ve alan tüm toplumları da etkilemektedir (Castles ve Miller, 2008, s.9-11). “Öncü göçmenler bir göç yolu oluşturunca gittikçe daha fazla sayıda gizil göçmen önceki göçmenlerden aldıkları bilgilerle oluşturulan bu yola katılır. Böylece gerçek göç yolları filizlenir" (Faist, 2003, s.202). Dolayısıyla belli bir kesimin göçü gerçekleştikten sonra bile, aile ve yakın çevreden etkilenerek gizil göçmenler ortaya çıkmaktadır. Bu da sadece hedef ülkeyi değil, aynı zamanda kaynak ülkeyi de belirlemektedir.

Uluslararası göçmenler tek-yönlü caddelerde değil, çift-yönlü anayollarda seyahat etmektedir. Sadece yeni yerleşim yerleriyle bağlantı kurmazlar, aynı zamanda ayrıldıkları ülkeyle de bağlar geliştirirler (Faist, 2003, s.22). Göç ve göçmen ağları, uluslararası göçün devam etmesine yardımcı olmaktadır. Bu ağlar, az mekândan bu kadar çok göçmene geçişi açıklamaktadır (Faist, 2003, s.265).

$\mathrm{Bu}$ durum uluslararası göçü modern göçten farklı bir yere oturtmamız açısından önemlidir. Zira aidiyet bilinci mekâna özgü ayırıcı birtakım özelliklerden ayrılmaktadır. Bunun yerine küresel çağın teknolojisi yerel kültürü göç edilen ülkenin kültürüne eklemlemektedir.

Küresel çağda, daha önce sınırlar ve vatandaşlar ile tanımlanan ulus devletin tanımı da giderek değişmektedir. Her ne kadar ulus devlet savunma, kamusal düzen ve refah açısından hala temel birim olsa da, iktidar ve ulusal sınırlar arasındaki bağlar ve özerk eylem kapasitesi zayıflatmaktadır (Castles ve Miller, 2008, s.59). Diğer taraftan, Seyla Benhabib'e göre, İkinci Dünya Savaşı'ndan beri uyruksuz insanların, mültecilerin ve sığınma hakkı arayanların koşullarının iyileştirilmesi için büyük adımlar atılmış olsa da, artan 
göç ile birlikte, Hannah Arendt'in ifadesiyle vatandaşlı̆̆ın kaybı ile insan haklarının tümden yitirilmesi eşit değerde görüldüğü gözlemi bütünüyle yanlış değildir (Benhabib, 2018, s.176).

"Göç, gidiş kadar gelişi de zorunlu kılar; yani eski ülkeden çıkışı ve yeni ülkeye adaptasyonu. Yurtdışında bulunma, önceki yurtta dokunaklı bir bulunmama anlamına gelir" (Faist, 2003, s.23). Göçmenler göç ettikleri topluma yalnızca uyum sağlamakla ve bu toplumdan bir şeyler öğrenmekle kalmazlar. Bunun yanı sıra bu toplumu değiştirirler ve yaşamlarını onun içerisinde üretirler (Faist, 2003, s.143). Eve yakınlık olarak ifade ettiğimiz yakın akrabalık ve arkadaşlık ilişkileri ne kadar fazlaysa göçmenin yerleşikliği ve geçmiş kültüre yakınlığı da o oranda artmaktadır. Bu bakımdan zincirleme göçün olanağı/olanaksızlığı, yakın ilişki ağları ile anlamlıdır. Burada göç edilen mekân önemsizleşirken, geçmiş mekânın yinelenebilir ağırlığı hedef ülkede ön plana çıkmaktadır.

\section{Geriye Dönüş Göçü}

Göç araştırmalarında kullanılacak yöntemle ilgili makalesinde Belkıs Kümbetoğlu göç edenlerin hedef ülkedeki pozisyonları hakkında bilgi vermektedir. Ona göre göç edenler, yer alacakları toplumsal alanda, yeni gelen, yabanc1, müphem olmaları gerekçesiyle, henüz bütünleşmemiş bir gruba işaret etmektedir (2018, s.75). Yeni gruba aidiyet sağlama girişimleri kolay olmamakla birlikte başka bir olasılık da mevcuttur. Bu yeni olasılık geçmişin izlerini takip etmekle başlayan köken bağlarıdır ve bu dolayımda gerçekleşen geriye göçtür.

Geri dönüş göçü, göç edenlerin köken ülkelerine dönmeleri anlamında eve dönmekten ibarettir. Geri dönen birçok göçmen, evi onlara ifade ettiği durumdan daha karmaşık bulur (Bartram, Poros, Monforte, 2017, s.261-2). Eve dönen, evden ayrılanla aynı kişi değildir. Eve dönen ne kendisi için ne de onun dönmesini bekleyenler için ayn kişidir (Schütz, 2018, s.341).

Göçün makro, mikro ve orta boyutlu düzeylerini ele aldığı çalışmasında Thomas Faist, geri dönüş söyleminin kişisel düzeyde yıkıcı amneziye karşı durmanın bir getirisi olarak ortaya çıtığından söz eder ve ekler; geri dönüş yönelimleri, kişi için, yalnızca alanın ${ }^{8}$ değil zamanın da fethedilebileceğinin

\footnotetext{
${ }^{8}$ Burada alan kavramı Faist tarafından eski göç deneyimlerindeki göçmen tanımlamalarından farklı olarak, kendi sosyal sermayesini (dilini, dinini, kimliğini, kültürünü ve benzeri) göç ettiği ülkede yaşa(y/t)an insanlar için kullanılmıştır.
} 
düşünmesini sağlar (Faist, 2003, s.399-400). Dolayısıyla geri dönüş göç eden kişi için bulunduğu alanı da kabul ettiği ve zamanın kurgusal dengesini buna göre ayarladığı bir hayatta kalış projesi haline gelmektedir. Bu hayatta kalış projesinde belki de en çok dikkatimizi çeken yön, kimlik tasarımıdır. Ulaşım olanaklarının geliştiği ve herkes için göç etmenin yaygın bir özellik olmadığı geçmiş dönemlerde kimlik, geleneksel bağlarla ilişkiliydi. Bugün ise sabit bir deneyimden ibaret olmayan kimlik; değişmekte, dönüşmektedir.

Bu bağlamda, bugün kimlik için ilksel bağlllıklardan biri olan toprak bağlılığı tartışmalı hale gelmektedir. Kimlik ortak bir toprağa aidiyet doğrultusunda değil, başkalık nosyonuna sarılmaktadır. Bu durum bizi, aidiyet ve kimliğin alınyazısı olmadığının, ömür boyu garanti sağlamadığının, fazlasıyla müzakereye açık ve vazgeçilebilir şeyler olduğunun farkına vardırır. Aidiyet alternatifsiz bir koşul olarak kaldığı sürece bir kimliğe sahip olma düşüncesi söz konusu olmayacaktır (Bauman, 2017, s.20). Dolayısıyla eve dönüş olasılığı, hareketliliğin varlık gerekçesi olarak değerlendirildiği küresel çağ koşullarında, olasılık dışı bir belirlenme olarak karşımıza çıkar. Üstelik bu geri dönüş çoğu zaman, Hayriye Erbaş'ın ülkemize yerleşen Suriyeli göçmenler üzerine yapmış olduğu analizde dile getirdiği gibi, hayata sıfır noktasında yeniden başlama ve yeniden bir mağduriyet anlamı taşır (2019, s.16).

Ülkeler açısından bakıldığında ise geriye göç, birey için ifade ettiğinden çok daha karmaşık bir bağlama sahiptir. Birleşmiş Milletler Mülteci Sözleşmesi (BMMYK) mülteci statüsünü sona erdirecek üç kalıcı çözümü gönüllü geri dönüş, yerel bütünleşme ve üçüncü bir ülkeye yerleşme olarak tarif etmektedir (2018, s.82). Görüldüğü gibi geri dönüş BMMYK'nin göçü önleme konusunda yapmış olduğu üç çözüm önerisinden biridir.

Ancak buna rağmen geriye dönüş tartışmalı pek çok sorunu da içerisinde barındırmaktadır. Sözgelimi Türk geriye dönüşün incelendiği bir çalı̧̧mada, ne motivasyonu ne de sonuçları için sadece tek bir nedenin (ekonomik) göç deneyimini açıklamada yetersiz, yüzeysel kalacağı öne sürülmüştür. Türk geriye dönüş durumu karmaşık ve çok katmanlı bir fenomen özelliği sergilemektedir (Kunuroğlu, van de Vijver, ve Yağmur, 2016, s.19-20).

Örnekte de görüldüğü gibi geri dönüş göçü tartışmalı bir meseledir; göç alan ve veren ülkeler arasında sürekli yerleşmeden geçici dolaşıma kadar farklı anlamlar ifade etmektedir. Diğer taraftan geri dönüş, göç alan ve ve- 
ren ülkeler arasındaki anlaşmalar, sınır kontrolleri ve işbirliği yoluyla istenmeyen göçmenlerin çıkarılması için bir araç olarak da görülmektedir (Bilecan, 2018, s.142-3).

Geriye göç kararları, iktisadi ve siyasi nedenlerden kaynaklı makro düzeyden bireysel bakış açılarının yer aldığı mikro düzeye kadar uzanır. Genel olarak pek çok neden ${ }^{9}$ aynı anda devrededir (Öner, 2018a, s.267-8). Diğer taraftan geriye göçün mahiyeti, kişinin yetiştiği ortama göre farklılık göstermektedir. Burada kişinin kültürel değerlerindeki farklılık ile yaşam şansının sağladığı avantajlar, göçün hangi boyutta tartışılacağını ortaya koymaktadır. Öyle ki kişi içinde bulunduğu toplumda avantajlı bir kültürel geçmişe sahipse tekrar göç ettiğinde de benzer tarzda karşılanmaktadır. Oysa dezavantajlı bir gruptan ve kimlikten aynı zamanda suça bulaşmışsa geriye dönüş olumlu bir çizgide gerçekleşmemektedir ve kabul çok da s1kıntılı bir hal almaktadır. Bütün bunların yanı sıra göçmenin göç ettiği ülkedeki pozisyonu da bir hayli etkilidir. Bu bakımdan Öner'in öne sürmüş olduğu gibi, tersine göçte olumsuz birtakım deneyimler kişilerde "tersine kültür şoku" ne neden olabilir (2018a, s.272). Dolayısıyla göçün kendisi kadar tersine göç deneyimi de karmaşık ve çok boyutlu bir süreçtir denilebilir.

\section{Sonuç}

Mekân kişileri ve toplumları aidiyet bağı ile ortak bir kültürün parçası haline getirmektedir. Ancak mekâna dayalı bilindik yaşantı, göçle dönüşüm geçirmektedir. Bu bireyde travma yaratabildiği gibi, ulus devletlerin temelinde yer alan bilindik ve kontrol edilebilir mekânı alt üst edebilmektedir. Bu açıdan eski ve korunaklı değerlerin yeniden nasıl muhafaza edilebileceği gündeme gelmektedir. Bu bağlamda geriye dönüş mümkün alternatiflerden biri olarak karşımıza çıkmaktadır. Ancak geriye dönüş her zaman bilindik olanın keşfi anlamına gelmemektedir. Söz konusu olan ne eskiye dönüş ne de yeniye adapte olmaktır. Bu bağlamda geriye dönüş, bireyler ve ülkeler için açık bir kafa karışıklığı yaratabilmektedir.

Geriye dönüş miti tartışılırken sadece göçmenlerin değil, göç alan ülkelerin de eski olana dönüşünün mümkün olmadığı öne sürülmelidir. Çünkü

\footnotetext{
${ }^{9}$ Geriye göçün Francesco Cerase'den yapılacak alıntıda olduğu gibi, farklı nedenleri ve buna dayalı türleri bulunmaktadır: Başarııızlık geri dönüşü, muhafazakârlık geri dönüşü, yenilikçi geri dönüşü, emeklilik geri dönüşü (1974, Öner, 2018a, s.267-8).
} 
eski kültürel yapı, göçle birlikte aktif bir değişime uğramaktadır. Bu sürecin sonucu her iki kültürün de birinin evini terk etmesi anlamında diğerinin eski düzenini koruması anlamında bildiği imajın sarsılmasıdır. Sonuç olarak eski düzen göçün artan ağırlığıyla her an yeniden kurgulanmaktadır. Bu en küçük topluluklardan en büyüğüne kadar insanlara her alanda yön verecek bir gelişmedir.

Eve dönüş kişisel düzeyde, yabancı olmanın yarattı̆ı travma hali ile mekânsal bir yer değişimini anlatmaktadır. Geriye dönüş ile hem yabancıya aşina olunmaktadır, hem de yerli olma imajı sarsılmaktadır. Bu durum olumsuz bir değerlendirme değildir. Bilakis tarihin başlangıcından beri göç vardır; dolayısıyla (yer) değişim(i) kaçınılmazdır.

Schütz'e göre gitmek, biraz da ölmektir (2018, s.336). Ancak küresel çağın koşullarında, kalmayı istemek de bir bakıma ölmektir. Doğduğu ülkeden gidenlerin sayısı giderek artmaktadır. Ancak bu bir sonuç değil başlangıçtır. Bu durum bizi dünyanın ortaklıklar üzerinde temel bulduğu sonucuna götürmektedir. Ortaklıklar yeni aidiyetleri inşa etmekte, inşanın bağlayıcı unsurları her an değişmektedir. Sonuçta, günümüz koşullarında, küresel hareketlilik hali insan var oldukça bu değişimi kaçınılmaz kılacaktır. 


\section{EXTENDED ABSTRACT}

\section{Homecoming In The Late Modern Age \\ Figen Kanbir \\ Siirt University}

The close connection between spaces and human and social life is already acknowledged. In all historical periods, many factors such as harmony, order, security have been associated with space. However, with migration, the binding effects of places on individuals have decreased. Migration disrupts the established order by staying in a place for a long term. In this respect, immigrants can be considered as potential threats to the old order. In order to make sense of this situation, we can set out from the distinction between internal and external migration, which is a classic conceptualization example in the migration literature. Although migration has a certain effect, it is observed that internal migration does not transform local cultures to a great extent and does not seriously distort human bonds. External migration, on the other hand, leads to the disappearance or transformation of existing local/conventional values. In this context, this study takes the notion of external migration as a reference point.

Migration has existed in every historical epoch. However, the reasons for migration differ. Castles and Miller state that migration, in a general sense, first emerged in the form of slave labour, contracted labour under the influence of industrialization, and asylum seekers or illegal immigration from the mid-1980s (2018, p. 71-91, 144). In this context, migration affects not only the countries that send or receive immigrants, but all the rest of the world. Migration has an influence on all economic, political and international relations around the world (Erbaş, 2019, p.265; Castles ve Miller, 2018, p. 29).

That is, immigration does not only have a binding effect for immigrants. Migration might have positive or negative consequences in various aspects in national and international contexts. Surely, the countries that host or send immigrants feel the decisive influence in the first place. In monitoring the positive and negative results, the qualifications of the immigrant population, besides the development level of the source and target countries, is a determinant. At this point, many reasons can speed up or slow down migra- 
tion. However, migration also involves risks in many ways. Due to the difficulty of controllability, new residents may pose a risk for the target countries. Because of the immigrants, the safety barrier is substantially disintegrated. In fact, new residents might lead to some uneasiness among the locals for their unpredictability.

Nevertheless, the experience of immigration constitutes some difficulties for the immigrants themselves. Immigration is a journey full of risks for the individual and the family setting out for an unknown life and being a stranger in the migrated country (Adıgüzel, 2019, p.3). Indeed, immigrants are addressed as a disintegrated group that is new, foreign, and obscure in the social area where they will settle down (Kümbetoğlu, 2018, p. 75). This understanding is far from being a valid assumption for every condition. Because the characteristics of the individual and the social structure differentiate the cause and effect of migration.

Considering the reasons for migration, it is seen that the individual's voluntary preferences do not always play a role. If voluntary displacements are left aside, migration might also be a result of a crisis. As a matter of fact, this situation takes us to Hayriye Erbaş's (2019, p.263) argument that "migrants do not create a crisis, on the contrary, crises create migrants".

In this scope, when we look closely at historical periods, we realize that the meaning of migration has changed in terms of being the motto of change. According to Özgöker and Doğan, whilst migration was advantageous from the beginning of history to industrial societies, in the global age it has been facilitated by increasing mobility. In the global world, migration has become a disadvantage rather than an advantage $(2019, \mathrm{p} .16)$. In the past, it facilitated communication between individuals, leading to transformation and progress. Today, migration has become possible for everyone. In this context, it can turn the constituents of space such as security, harmony and regularity upside down. This condition directs our attention to the necessity of controlling migration.

The United Nations Refugee Convention expresses voluntary returns as one of the three permanent solutions to end the refugee status (2018, p.82). Return migration is a multidimensional problem when considering society, culture, and identity. This problem basically originates from being in an inbetween status. In other words, it has different degrees of influence in terms of the country from which they migrate, and they are hosted. 
However, considering this issue from a broader perspective reveals different causes of return migration. The return depends on many reasons, from macro to micro levels. In general, many reasons are simultaneously active and valid (Öner, 2018a, p.267-8). It is not always possible to confirm the willingness of the individual in return migration, as in migration itself. The differences in cultural values and the advantages of the chance of survival reveal the extent of migration. Taking this into consideration, these different reasons need to be interpreted. As a matter of fact, migration can be either voluntary or involuntary. Herein, the success or failure of the individual is effective. Another reason is their inability to fully adapt to the original or target culture.

Return migration has many different meanings, from permanent settling to temporary circulation in the receiving and sending countries. Return migration is also seen as a tool for the dismission of unwanted migrants through agreements, border controls and cooperation between the receiving and sending countries (Bilecan, 2018, p. 142-3).

In this context, the aim of this study is to read the reverse flow of migration and to inquire the reasons behind the immigrants' return. Despite the fact that space stabilizers are reduced in the global age, homesickness remains as a possible alternative for humanity. For this reason, it constitutes one of the issues worth examining.

\section{Kaynakça / References}

Abadan-Unat, N. (2017). Bitmeyen göç: Konuk işçilikten ulus-ötesi yurttaşlğga. (3. Bask1). İstanbul Bilgi Üniversitesi Yayınları.

Adıgüzel, Y. (2019). Göç sosyolojisi. (3. Bsm). Ankara: Nobel Yayınclık.

Akçapar, Ş. K. (2018). Uluslararası göç alanında güvenlik algılamaları ve göçün insani boyutu. (4. Baskı). (Der. S.G. Ihlamur-Öner ve Öner, N. A. Ş.). İstanbul: İletişim Yayınları, 563-575.

Anderson, B. (2017). Hayali cemaatler: Milliyetçiliğin kökenleri ve sınırları. (9. Basım). (Çev. İ. Savaşır). İstanbul: Metis Yayınları.

Arendt, H. (2013). İnsanlık durumu. (Çev: B. S. Şener). İstanbul: İletişim Yayınları.

Bartram, D., Poros M. V. ve Monforte, P. (2017). Göç meselesinde temel kavramlar. (Çev: I. A. Tuncay). Ankara: Hece Yayınları.

Bauman, Z. (2010). Küreselleşme: Toplumsal sonuçları. (3. Basım). (Çev: A. Yılmaz). İstanbul: Ayrıntı Yayınları. 
Bauman, Z. (2017). Kimlik. (Çev. M. Hazır). Ankara: Heretik Yayınları.

Bauman, Z. (2018). Kapımızdaki yabancılar. (Çev: E. Barca). İstanbul: Ayrıntı Yayınları.

Benhabib, S. (2018). Ötekilerin hakları: Yabancılar, yerliler, vatandaşlar. (4. Baskı). (Çev: B. Akkılay). İstanbul: İletişim Yayınları.

Bilecan, T.(2018). Geri dönüş göçüne etki eden faktörler: Göç literatürüne eleştirel bir bakış. Uluslararası Sosyal Araştırmalar Dergisi. 11(56),138-144.

Castles ve M. (2008). Göçler çă̆ı: Modern Dünyada uluslararası göç hareketleri. (3. Basım). (Çev: İ. Akbulut, B. Bal). İstanbul Bilgi Üniversitesi Yayınları.

Erbaş, H. (2019). Sunuş. Gidişlerden Kaçışlara Göç ve Göçmenler (Kuram, Yöntem ve Alan Yazıları. Ankara: Phoenix Yayınları.

Faist, T. (2003). Uluslararası göç ve ulusaşırı toplumsal alanlar. (Çev: A. Z. Gündoğan, C. Nacar). İstanbul: Bağlam Yayıncilık.

Geertz, C. (2010). Kültürlerin yorumlanması. (Çev: H. Gür). Ankara: Dost Kitabevi Yayınları.

Giddens A., ve Sutton P. W. (2014). Sosyolojide temel kavramlar. (Haz. ve Çev: A. Esgin). Ankara: Phoenix Yayınları.

Göç Araştırmaları Vakfı (2008). Dünya göç raporu.

Güler, A. (2018). Şartlı mülteci statüsü: Statünün geçiciliği ve bir kalıcı çöüzüm olarak yerel bütünleşmenin geçerliliği. (Der: H. H. Aygül, E. Eke). 21. Yüzyılda Uluslararası Göç ve Mülteciler: Bir Türkiye Perspektifi. İçinde (s.7396). Ankara: Nobel Yayınları.

Hobsbawn, E. J. (2017). 1780'den günümüze milletler ve milliyetçilik: Program, mit, gerçeklik. (6. Basım). (Çev: O. Akınhay). İstanbul: Ayrıntı Yayınları.

Husserl, E. (2017). Fenomenoloji üzerine beş ders. (4. Baskı). (Çev: H. Tepe). Ankara: BilgeSu Yayıncilı.

Ihlamur-Öner, S. G. (2018). Yöntemsel milliyetçilik bağlamında insan hareketliliği ve uluslararası ilişkiler. (Der: N. A. Ş. Öner, S. G. Ihlamur-Öner). Uluslararası İlişkilerde Göç: Olgular, Aktörler ve Politikalar, içinde (s.21-46.),İstanbul: Der Yayınları,

Karakaş, M. (2019). Kent, Mekân ve Toplum: Mekân Sosyolojisine Giriş. (Ed: M. Karakaş). Kent, Mekân ve Toplum. içinde (s.15-40.)İstanbul: Tezkire Yayınc1lik.

Kunuroğlu, F., van de Vijver, F. ve Yağmur, K. (2016). Return migration. Online Migration in Psyhology and Culture. 8(2), 1-28.

Kümbetoğlu, B. (2018). Göç çalışmalarında "nasıl" sorusu. (4. Baskı). (Der: S. G. Ihlamur-Öner, N. A. Ş. Öner). İstanbul: İletişim Yayınları. 
Kymlicka, W. (1998). Çokkültürlü yurttaşlı: Azmlık haklarmın liberal teorisi. (Çev: A. Yılmaz). İstanbul: Ayrınt Yayınları.

Marshall, G. (1999). Sosyoloji sözlï̈̆̈̈̈. (Çev: O. Akınhay, D. Kömürcü). Ankara: Bilim ve Sanat Yayınları.

Modood,T. (2014). Çokkültürcülük: Bir yurttaşlı tasarımı. (Çev: İ. Yılmaz). Ankara: Phoenix Yayınevi.

Öner, N. A. Ş. (2018). Göç çalışmalarında temel kavramlar. (4. Baskı). (Der: S. G. I. Öner, N. A. Ş. Öner). İstanbul: İletişim Yayınclık, 13-27.

Öner, N. A. Ş. (2018a). Son Mu, Başlangıç mı? Göç çalışmalarında sosyal bir olgu olarak geri dönüş. (4. Baskı). (Der: S. G. I. Öner, N. A. Ş. Öner). İstanbul: İletişim Yayıncllk, 263-285.

Rawls, John (2006). Halklarn yasası ve "kamusal akıl düşüncesinin yeniden ele alınması. (Çev: G. Evrim). İstanbul: Bilgi Üniversitesi Yayınları.

Schütz, A. (2018). Fenomenoloji ve sosyal bilimler. (Çev: A. Akan, S. Kesikoğlu). Ankara: Heretik Yayınları.

TDK. (t.y) Türkçe sözlük. http://sozluk.gov.tr/ adresinden erişilmiştir.

Tuna M., ve Özbek Ç. (2018). Yerlileşen yabancilar: Güney Ege Bölgesi'nde göç:Yurttaşlık ve kimliğin dönüşümü. (2. Baskı). Ankara: Detay Yayınları.

Türker, N. (2015). Vatanım yok memleketim var İstanbul Rumları: Mekân-bellek-ritüel. İstanbul: İletişim Yayınları

\section{Kaynakça Bilgisi / Citation Information}

Kanbir, F. (2020). Geç modern çağda eve dönüş homecomıng in the late modern age. OPUS-Uluslararası Toplum Araştırmaları Dergisi, 15(25), 3851-3873. DOI: 10.26466/opus.634744 